\title{
The glaciation of Serra de Queixa-Invernadoiro and Serra do Gerês-Xurés, NW Iberia. A critical review and a cosmogenic nuclide $\left({ }^{10} \mathrm{Be}\right.$ and $\left.{ }^{21} \mathrm{Ne}\right)$ chronology
}

\author{
VIDAL ROMANÍ ${ }^{1}$, J. R, FERNÁNDEZ MOSQUERA, D. ${ }^{2}$, Y MARTI, K. ${ }^{3}$
}

(1) Instituto Universitario de Geología. University of Coruña, Campus de Elviña s/n. 15071 A Coruña (Spain). (*) corresponding author xemoncho@udc.es

(2) Instituto Universitario de Geología. University of Coruña, Campus de Elviña s/n. 15071 A Coruña (Spain)xemos@udc.es

(3) University of California, San Diego. Department of Chemistry \& Biochemistry (0317), 9500 Gilman Drive, 5322 Mayer Hall, La Jolla, California 92093-0317. U.S.A. kmarti@ucsd.edu

https://doi.org/10.17979/cadlaxe.2015.38.0.3681

\begin{abstract}
The Serras of Queixa-Invernadoiro and Gerês-Xurés in the NW of the Iberian Peninsula are two small mountain massifs located at low altitude that were glaciated in the Pleistocene. The prevailing granitic lithology was a problem for mapping glacial forms (in many cases interpreted as banal granite forms) and for the identification of the tills (misunderstood as remains of regolith). A combination of geomorphological techniques (genetic mapping of granite forms and deposits), the micromorphological study of till thin sections and the morphoscopy of quartz grains at the SEM enabled to establish a model of the geomorphological evolution complemented with the chronology by cosmogenic nuclides ( $21 \mathrm{Ne}$ and $10 \mathrm{Be}$ ) of both glacial systems. The obtained results represent the glacial evolution of the area from circa $250 \mathrm{ka}$ B.P.
\end{abstract}

Keywords: glaciation, cosmogenic nuclides chronology, NW Iberian Peninsula, till, moraine, Pleistocene. 



\section{INTRODUCTION}

The first works on the Pleistocene of the NW of the Iberian Peninsula have more than one century (Hult, 1873). Since then and up to 1990, with the exception of purely geomorphological works (Coudé-Gaussen, 1978, 1980, 1981; Hernández-Pacheco, 1949, 1957; Schmidt-Thomé, 1983), the study of the glaciation in the zone did not raise much interest due to the reduced area of the glaciated surface (Pérez González et al., 1989), even in the Iberian glacial context. The glacial erosional forms and deposits are scarce being usual the confusion of common forms in non-glaciated granite terrains with glacial cirques and polished surfaces (Twidale and Vidal Romaní, 2005).

The most frequent deposits are till s.l. and moraines. The former has been interpreted as remains of granite regolith though this does not occur in the glaciated zone (Vidal Romaní et al., 1990 a and b). The moraines (push or lateral) (Vidal Romaní et al., 1990 a and b; Brum et al., 1992, 1993; Twidale and Vidal Romaní, 2005) with a few exceptions, originate ambiguous morphologies that have been misunderstood as accumulations of residual blocks or slope deposits (Teixeira and Cardoso, 1979; Martínez de Pisón and Arenillas, 1979, 1984). The proglacial deposits (essentially fluvioglacial terraces) escaped notice either due to their small dimensions, or because they were interpreted as simple torrential terraces. Very active periglacial dynamics, synglacial and postglacial (Texier and Meireles, 2003), contributed to mask the glacial features with a generalized regularization of slopes covering the glacial deposits (Brum et al., 1992, 1993). These facts together with the low altitude and geographic location of the moun- tains even led to the questioning of the existence of glaciation in the region (Teixeira and Cardoso, 1979; Martínez de Pisón and Arenillas, 1979, 1984).

The initial geomorphological interpretation established a classic pattern of glacial cirques with associated valley glaciers (Coudé-Gaussen, 1978, 1980, 1981; HernándezPacheco, 1949, 1957; Schmidt-Thomé, 1973, 1983; Pérez González et al., 1989). However, since 1990, the glaciation of NW Iberia has been studied more systematically with special interest on the glacigenic deposits (Vidal Romaní et al., 1990 a and b; Brum et al., 1992, 1993). This new stage in the research consisted in the identification and micromorphological study of the subglacial tills providing complementary data to the sometimes confusing geomorphological features. This research enabled to define the glacier limits with greater precision and to establish the ice dynamics in more detail.

Most authors of the previous works attributed the glaciation of NW Iberia to the Würm without having carried out any dating (Coudé Gaussen, 1978, 1980, 1981; Hernández-Pacheco, 1949, 1957; Maldonado, 1994; Schmidt-Thomé, 1973, 1983). Only one author (Hernández Pacheco, 1957) describe remains of an older glacial phase for the Serra de Queixa glaciation (Ourense, Spain), attributing it to the Riss though again without absolute datings. The difficulties for obtaining an absolute chronology were essentially due to the predominantly erosive character of the glacial systems of the zone and to the scarce sedimentation, which is also mainly detrital. The only sediments that may be dated by radiocarbon accumulate in the glacial overexcavated basins near the present divides (Fig. 1) (Laguna Grande, Serra de Queixa-Invernadoiro, Maldonado, 1994; 
Vidal Romaní et al., 1995) or in a proglacial setting (Lagóa de Marinho, Serra do GerêsXurés, Ramil-Rego et al., 1998). The oldest and most continuous sedimentary records of the zone have been preserved in those sites. However, their maximum age is 15 ka B.P. (14C), thus corresponding to a late stage of the later glacial or postglacial times.

So, the chronological model proposed for the west of the Spanish Pyrenees (Vilaplana, 1981; Bordonau, 1992), with a maximum age of $60 \mathrm{ka}$ B.P., was initially assumed as valid for all the Cantabrian Chain, including Galicia (Jiménez, 1996; Vidal Romaní et al., 1995) and the north of Portugal (Brum Ferreira, et al., 1992). The extension of the Pyrenean chronology to the Iberian NW caused problems of correlation because the rocky substratum is not the same. Also, neither the dimensions of the glaciation of the Pyrenees and of the Iberian NW nor the types of deposits and glacial forms present in both zones are comparable. As for example, glacial polish or striae typically found in any common glaciated landscape in the NW Iberian granite areas are scarce and only preserved in quartz dykes or in individual feldspars (Vidal Romaní et al., 1990 a and b). The postglacial weathering of the glaciated surfaces, though not intense (Soares de Carvalho and Lopes Nunes (1981) calculate the postglacial degradation in $15 \mathrm{~mm}$ thick) has greatly eliminated the glacial polish surfaces. Other types of forms and glacial deposits, frequent in the other glaciated areas of Iberia, are very scarce in NW Iberia.

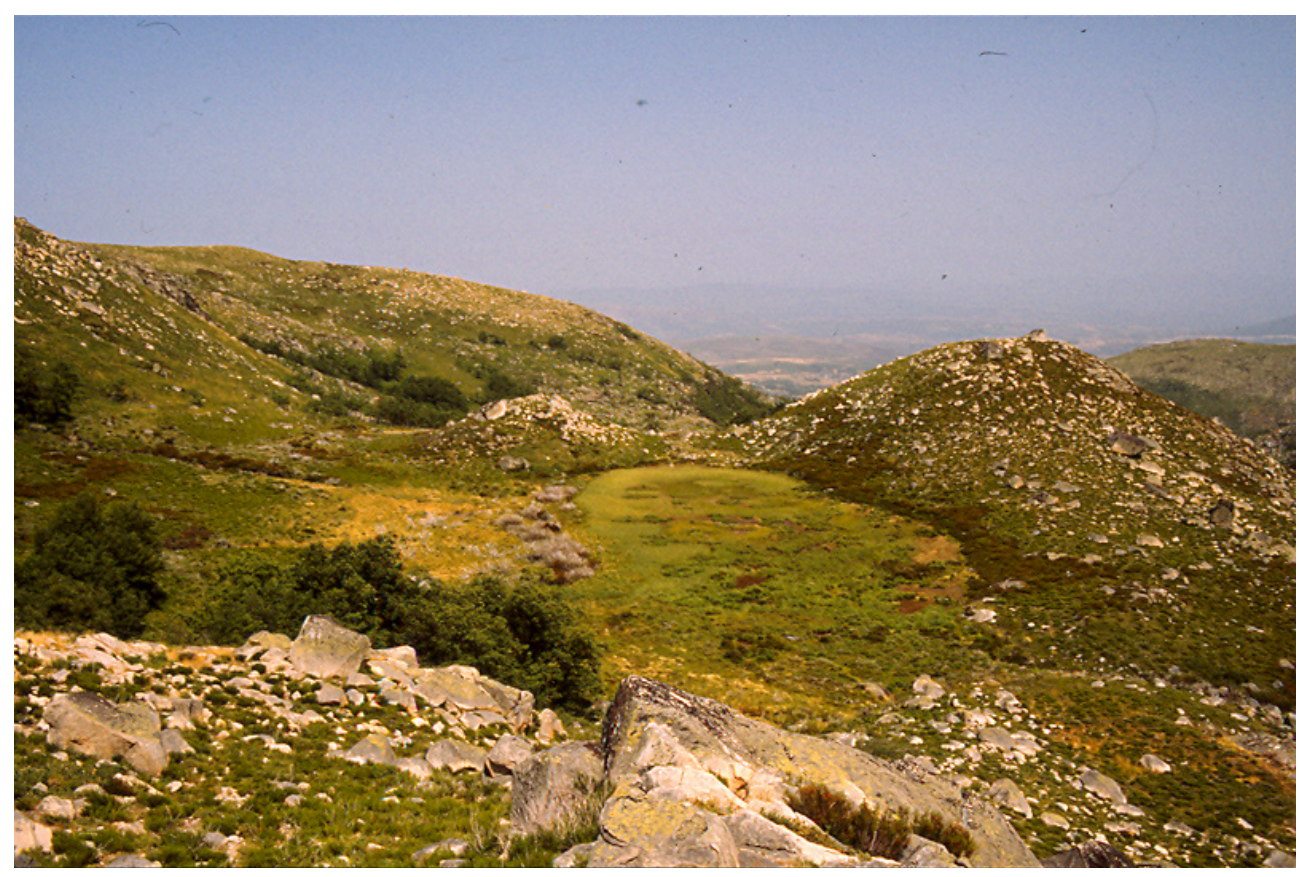

Fig. 1. 


\section{REGIONAL SETTING.}

Serra de Queixa-Invernadoiro and Serra do Gerês-Xurés are located in the NW of the Iberian Peninsula (Fig. 2). Serra de Queixa-Invernadoiro is the most important mountain of the province of Ourense (Galicia, Spain) and its higher height corresponds at Cabeza de Manzaneda (1778 $\mathrm{m})$. It is delimited by the Sil River in the north, Xares and Bibei Rivers in the east, Camba and Támega rivers in the south and by the riverheads of the Limia and Arnoia rivers. The lithology of Serra de QueixaInvernadoiro is a pre to synkinematic alkaline two-mica granite (Rubio and Rodríguez, 1981). This area is totally within the Spanish territory. The other studied zone, Serra de Gerês-Xurés, is mostly in the Por- tuguese territory inside the National Park of Peneda-Gerês in the North of the province of Minho with a small area of $2 \mathrm{~km} 2$ in the Spanish territory. It is located between the divides of the Limia River in the south of the province of Ourense and the Cávado River in the North of the province of Minho. In Serra de Gerês-Xurés there starts a river course of secondary order, the Homem. This river forms the main drainage axis of the glaciated area. The highest point of Serra de Gerês-Xurés is at Pico Altar de Cabrões (1508 m). The lithology of Serra de Gerês-Xurés is a biotitic granodiorite (Fernández and Pilas, $1974 \mathrm{a}$ and b) of medium to coarse grain. According to Cottard (1979), the fine-grained granite of Carrís and the porphyritic granite of Gerês prevail in the Portuguese zone.

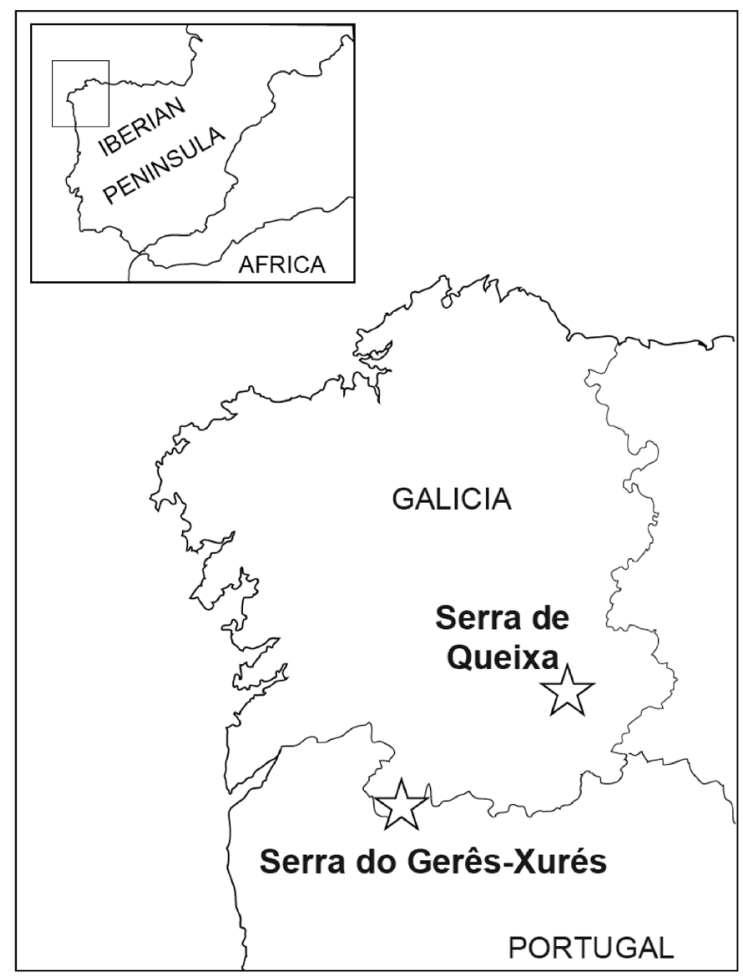

Fig. 2. 


\section{MATERIALS AND METHODS}

\subsection{Geomorphological definition of the glacial dynamics:}

The glaciated area has been defined using different geomorphological criteria: landforms and deposits of glacial origin (roches moutonnées, glacial polished surfaces, moraines, supraglacial and subglacial tills), granite forms (tor, castellated rocks and gnammas, essentially), and finally, the areas covered or not by granite regolith which allowed us to establish the maximum perimeter of the surface affected by the ice. For example, the gnammas and the big gra- nitic residuals (tor and castellated rocks) are only present outside the glaciated area (De Uña and Vidal Romaní, 2000).

These data were used to establish either the relative chronology of the glacial evolution or the maximum extent of the glaciation in both mountains (Figs 3a and $b ; 4 a$ and $b)$. Finally, though it is not of preferential interest for this work, the thickness reached by the ice during the glacial maximum has been approximately established according to the height of the lateral moraines above the present bottom of the valley. The values presented herein are approximate and give illustrative magnitudes.

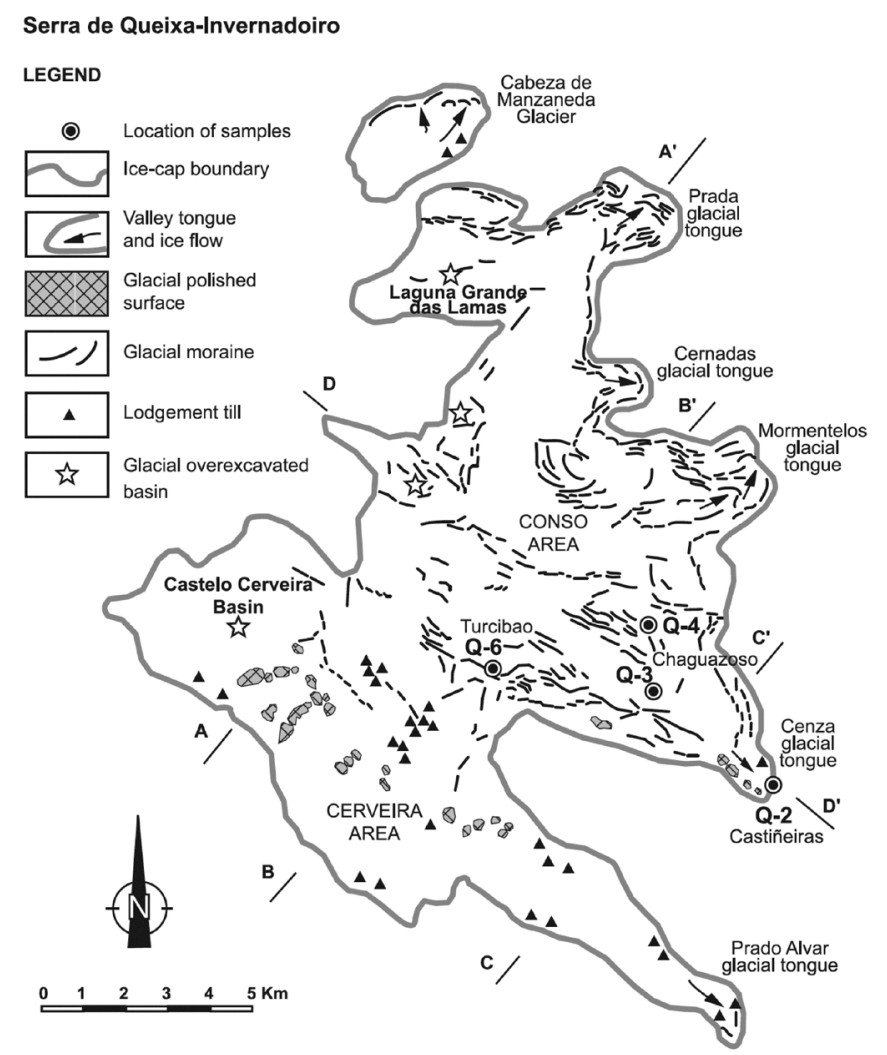

Fig. 3a. 


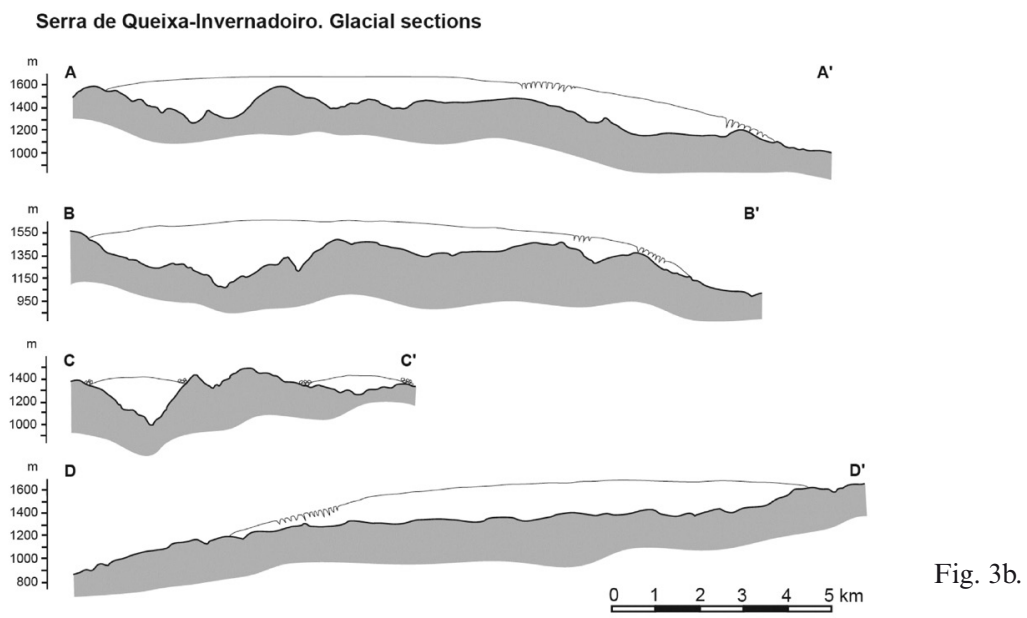

\subsection{Absolute chronology:}

According to the geomorphological and sedimentological observations a selection of glacial polished surfaces and deposits (moraines) that represents the main phases of glacial evolution in both zones was carried out. In both cases, when possible, quartz dyke samples were collected. There were taken into account the topographic determinants to avoid temporal and spatial shielding (Cerling and Craig, 1994). For example, sample Q-2 (Fig. 3a) is affected by topographical shielding from an adjacent boulder. So, the production rate at this site was corrected according to Dunne et al. (1999), with a shielding coefficient of $15 \%$.

The samples were obtained with a rock drill from bedrock or moraine boulders. We assume that the glacial erosion obliterated the pre-exposure record of cosmic radiation. When the samples were collected from moraine formations, largest boulders were selected in order to avoid multiple exposure stages.
The top $5 \mathrm{~cm}$ from the cores were cut and ground to several grain sizes. Optical inspection of the granite or quartz separates revealed that the 0.5 to $0.95 \mathrm{~mm}$ fraction showed the cleanest quartz grain abundance; thus, this fraction was used to separate the quartz for cosmogenic $21 \mathrm{Ne}$ measurements. Remaining fractions were sent for AMS 10Be measurements to PRIME Lab of Purdue University (U.S.A.).

Sample preparation for $21 \mathrm{Ne}$ measurements began with a chemical etching for purifying quartz separates. This process was done following procedures described by Kohl \& Nishiizumi (1992) and Dunai (2000) with minor variations. In order to reduce nucleogenic Ne concentration we must remove an outer shell of the quartz crystal equivalent to the alpha particles penetration depth. Changing chemical etching conditions (time and reagents concentrations) can improve the procedure yielding, saving more quartz for the measurement. Final inspection of the etched separates was done under the binocular microscope. Any quartz grain 
showing dots or feldspar intergrowth was rejected for analyses.

To further resolve the remaining nucleogenic Ne component, as well as trapped $\mathrm{Ne}$, the gas was extracted from the quartz grains using stepwise pyrolysis at temperatures from $300^{\circ} \mathrm{C}$ to $1200^{\circ} \mathrm{C}$ and melting at $1600^{\circ} \mathrm{C}$. Extraction times were $30 \mathrm{~min}$ up to $800^{\circ} \mathrm{C}$, and $20 \mathrm{~min}$ for higher temperatures. We followed the procedures of Niedermann et al. (1993, 1994) and Niedermann (2000) in the analyses of $\mathrm{Ne}$ by static mass spectrometry at Scripps Institution of Oceanography-UCSD (La Jolla, U.S.A.).

In Serra de Queixa-Invernadoiro (Fig. $3 \mathrm{a}$ and $\mathrm{b}$ ) four samples were collected: $\mathrm{a}$ moraine boulder (Q-2) near Castiñeiras corresponding to the maximum advance and which should bear the oldest age for the glaciation of the zone. The following sample corresponds to a moraine boulder (Q-6) in Turcibao located between $1500 \mathrm{~m}$ and $1450 \mathrm{~m}$ ASL in the divide between the Conso and Cerveira rivers. It was deposited when the Serra de Queixa-Invernadoiro original ice cap separated into two different glaciers draining along the present valleys of
Conso and Cerveira Rivers. In this stage the ice volume was considerably smaller than the maximum represented by the Castiñeiras moraine. The third sample (Q-3) corresponds to the surface of a roche moutonnée located beneath the Chaguazoso moraine. In that moment both glaciers kept their independent evolution. Finally, another sample (Q-4) was taken from a glacial polished bedrock in the most inner zone of Glacier of Conso and corresponds to a late stage in the deglaciation.

In Serra do Gerês-Xurés (Fig. 4a and b), most of the glaciated area is located in the Portuguese zone, inside the Natural Park of Peneda-Gerês, an area with sampling restriction. So, we had to sample only the Spanish zone, which, as stated before, was affected by the ice during a diffluence stage. Therefore, the obtained date corresponds to the oldest glacial maximum preserved in the zone. Two samples were taken: $\mathrm{X}-1$ in the same divide of the diffluence col of the Vilamés River, and X-2 among 3 push moraines which correspond to a local glacial maximum. 


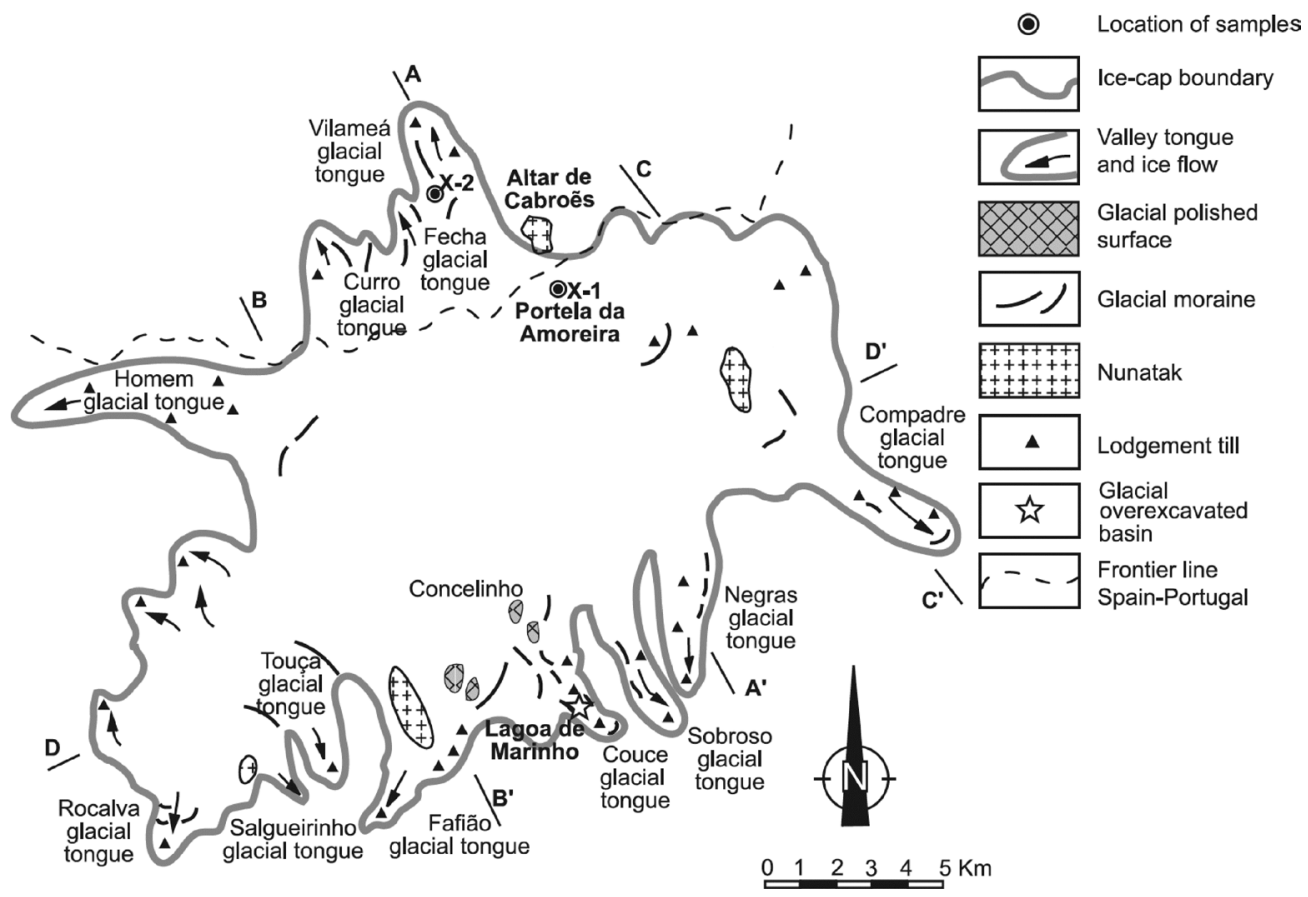

Fig. 4a.

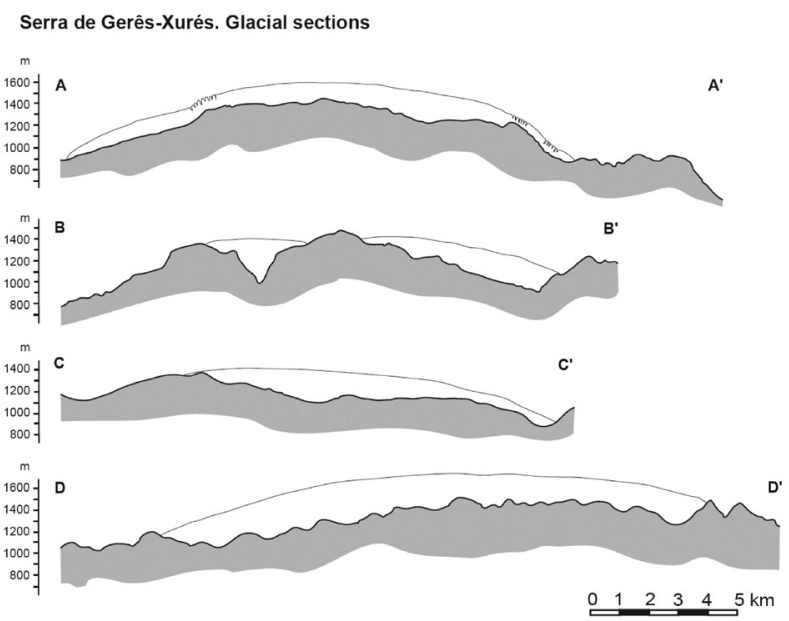

Fig. 4b. 


\section{RESULTS}

We have identified 4 different types of till: lodgement till, subglacial melt-out till, deformational till and supraglacial or ablation till.

From these four types, the lodgement till gives greater information on the glacial dynamics. It appears in discontinuous and small outcrops not easy to map at the scale presented here. Therefore, only their approximate position is shown. All the outcrops of lodgement till present similar characteristics. It is a detrital sediment with a very compact sandy-muddy matrix (matrix supported) (Fig. 5), foliation in the contact with the bedrock (Fig. 6), and abundance of blocks with faceted shape of glacial origin. The texture is grain-supported though sometimes the very abundant matrix may separate the grains. Under the optical microscope the matrix shows brecciated-mylonitic facies with angular grains of quartz and feldspar, which may appear occasionally rounded. In some cases it is possible to observe a skelsepic fabric typical of the lodgement till (Fig. 7). The morphoscopy of the quartz grains at the SEM shows striae, conchoidal fractures and steps, typical of sedimentary environments of high deformation like the subglacial ones.

In Serra de Queixa-Invernadoiro (Figs $3 \mathrm{a}$ and $\mathrm{b})$ the cosmogenic chronology obtained for the 4 samples (Table 1) (Vidal Romaní et al., 1999; Fernández Mosquera et al. 2000) is coherent with the geomorphological relative chronology, that is, progressively more modern from outside to inside the glaciated zone. For this zone there also exists (Vidal Romaní et al., 1990 a and b) a minimum age of 13.4 ka B.P. (14C) (Vidal Romaní and Santos, 1993) in the base of the sequence accumulated in the overexcavated glacial basin of Laguna Grande-As Lamas (Fig. 1). When this sequence began to accumulate (it starts with a lodgement till) there still persisted a small mass of glacial ice in the zone because the age of sample Q-4 and the one of the base of the sequence of Laguna Grande-As Lamas are similar.

The age of Q-2 $(155 \pm 30 \mathrm{ka}$ B.P. $(21 \mathrm{Ne}))$ corresponds to a glacial maximum in the area. Q-3 (22 $\pm 17 \mathrm{ka} \mathrm{B.P.}(21 \mathrm{Ne})$ and $23 \pm$ 2 ka B.P. (10Be)) and Q-6 (85 \pm 24 ka B.P. $(21 \mathrm{Ne})$ ), though internal to the perimeter of the glaciated area, mark two different advances of minor entity in the glacial evolution of the sierra. Q-6 indicates the separation of the initial, unique ice cap into two glaciers (Conso and Cerveira areas) that evolved as independent systems in the final stage of Queixa-Invernadoiro. Q-3 has the peculiarity of being the moraine of with the biggest dimensions (40 $\mathrm{m}$ thick).

In Serra do Gerês-Xurés (Figs $4 \mathrm{a}$ and b) the studied samples correspond to a diffluence zone active during a glacial maximum (Brum et al., 1992, 1993; Vidal Romaní et al., 1990 a and b; Vidal Romaní et al., 1999; Fernández Mosquera et al. 2000). By then, there were generated the glacial tongues of Fecha, Curro and Vilamés (Vidal Romaní et al., $1990 \mathrm{a}$ and b). The first sample (X1) $(131 \pm 31 \mathrm{ka} \mathrm{B.P.}(21 \mathrm{Ne}))$ corresponds to a glacial polished bedrock located in the Portela da Amoreira, at the riverhead of the Vilamés River below the residual of Altar

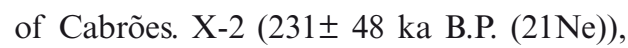
among 3 morainic ridges, is located on the west slope of the valley of the Vilamés River and is also a glacial polished bedrock exposed after a previous glacial maximum (Vidal Romaní et al., 1990 a and b; Brum et al., 1992, 1993). 


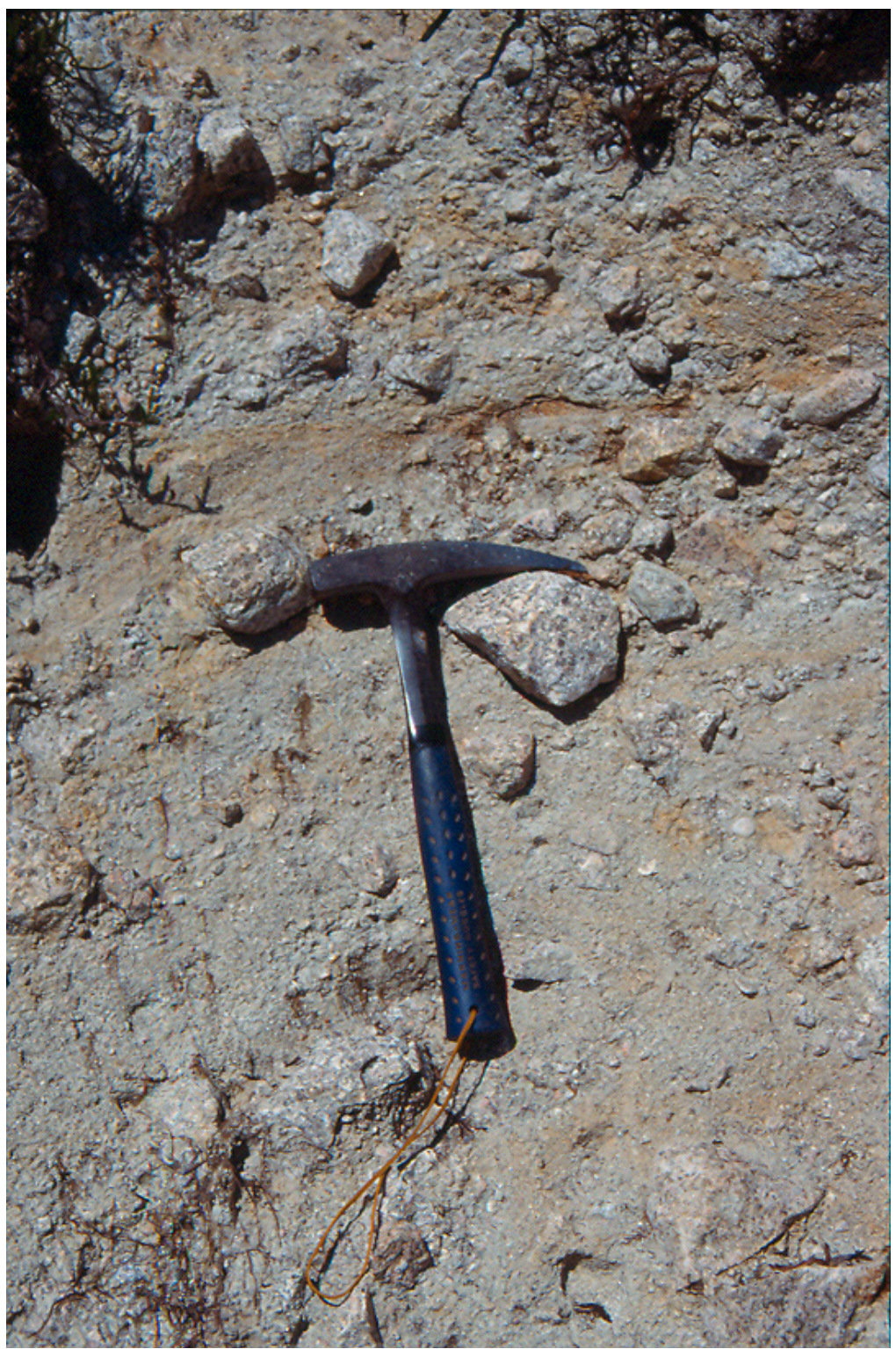

Fig. 5 . 


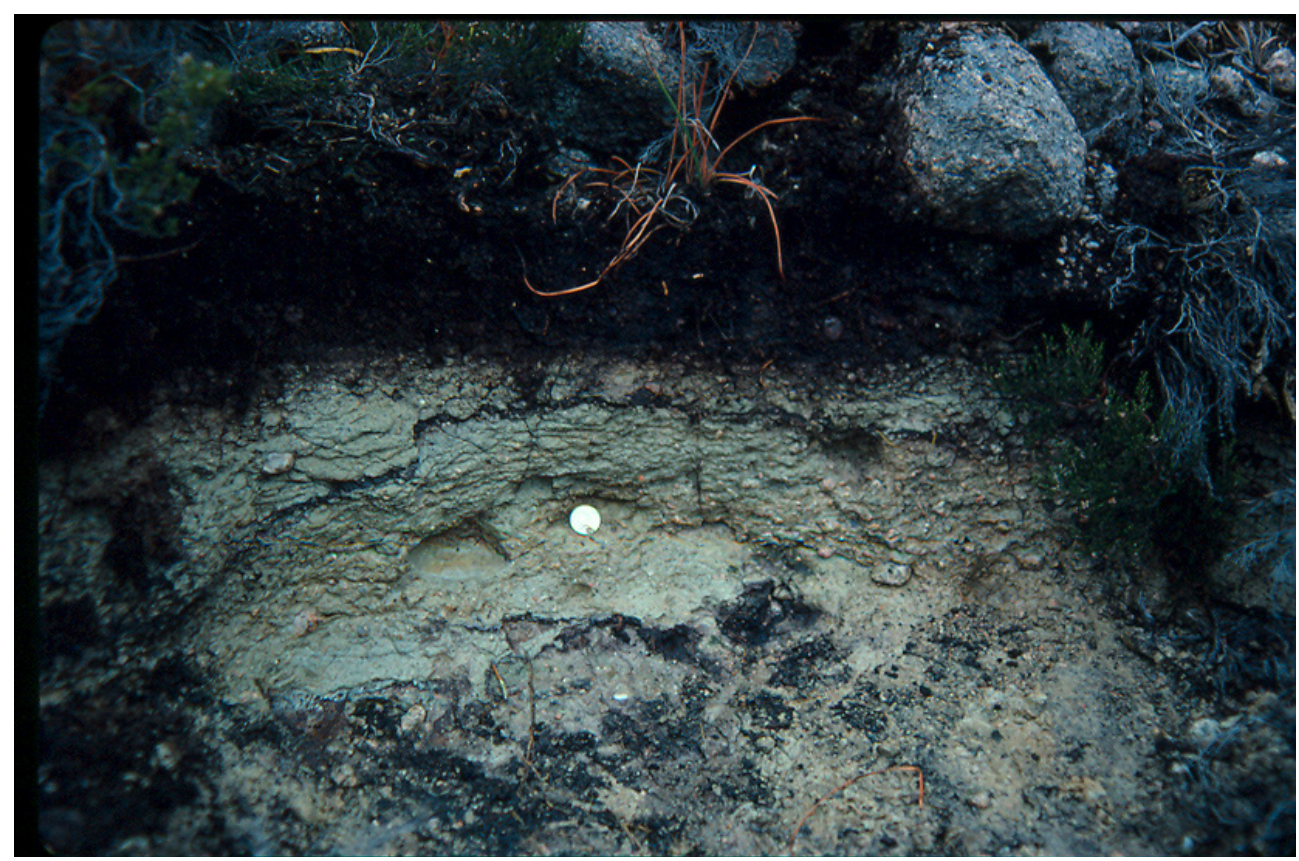

Fig. 6.

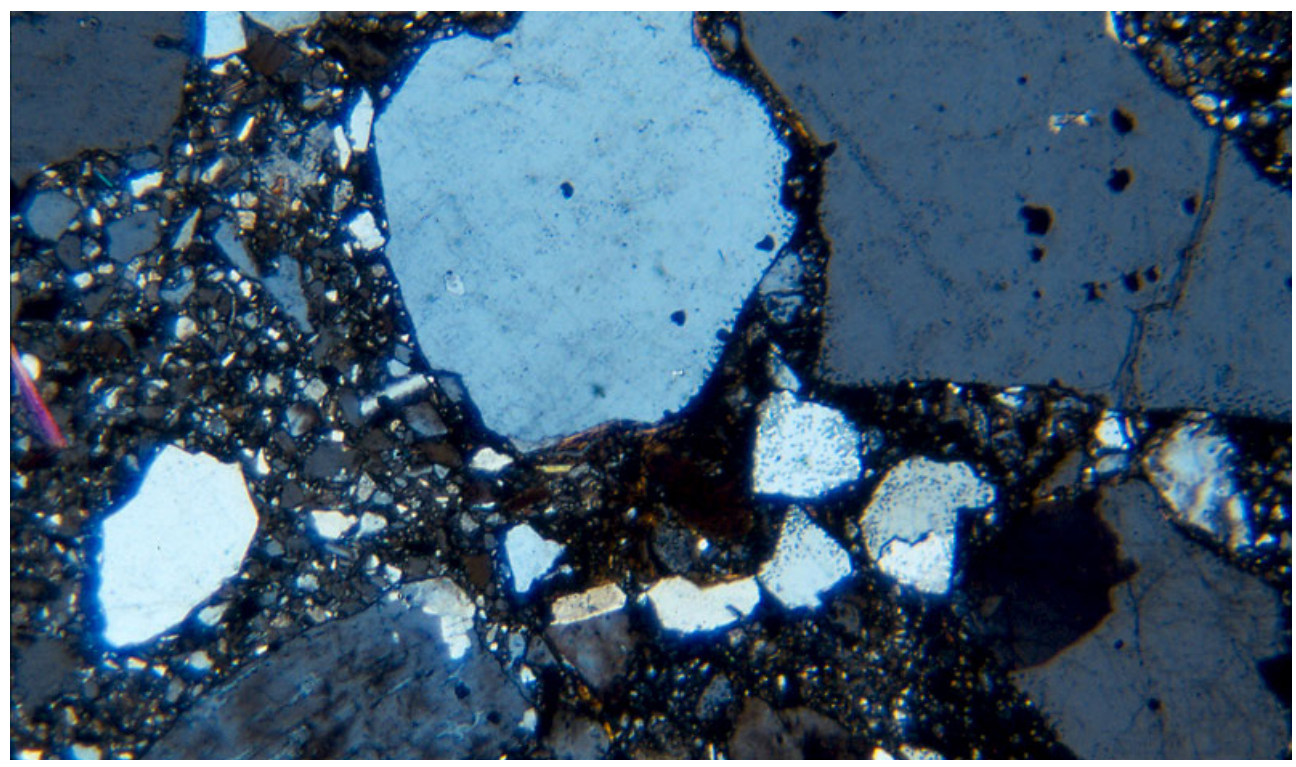

Fig. 7. 


\begin{tabular}{|c|c|c|c|c|c|c|}
\hline 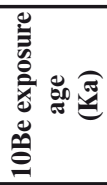 & & $\begin{array}{l}N \\
+1 \\
\tilde{N}\end{array}$ & $\left|\begin{array}{c}N \\
+1 \\
\pm\end{array}\right|$ & & & \\
\hline 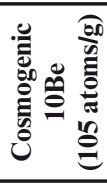 & & $\begin{array}{l}n \\
0 \\
+1 \\
+1 \\
\tilde{\sigma} \\
m\end{array}$ & $\begin{array}{c}0 \\
0 \\
0 \\
+1 \\
0 \\
i \\
i\end{array}$ & & & \\
\hline 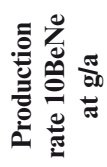 & & $\begin{array}{l}5 \\
0 \\
0\end{array}$ & $\left|\begin{array}{l}n \\
b \\
i\end{array}\right|$ & & & \\
\hline 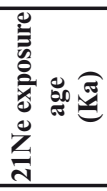 & $\begin{array}{l}0 \\
\infty \\
+1 \\
n \\
n \\
n\end{array}$ & $\begin{array}{l}\Xi \\
+1 \\
\approx\end{array}$ & $\begin{array}{l}r \\
+1 \\
0 \\
-1\end{array}$ & $\begin{array}{l} \pm \\
\sim \\
+1 \\
\sim \\
\infty\end{array}$ & $\begin{array}{l}\vec{m} \\
+1 \\
\vec{m}\end{array}$ & 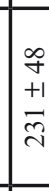 \\
\hline 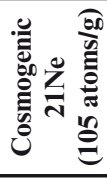 & 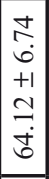 & $\begin{array}{l}a \\
a \\
+1 \\
0 \\
0 \\
= \\
=\end{array}$ & $\begin{array}{l}\tilde{n} \\
\hat{m} \\
+1 \\
\tilde{\sigma} \\
\dot{b} \\
\end{array}$ & $\begin{array}{l}- \\
\dot{ \pm} \\
+1 \\
a \\
a \\
\dot{q}\end{array}$ & $\begin{array}{l}0 \\
0 \\
2 \\
+1 \\
0 \\
i \\
i \\
i\end{array}$ & $\begin{array}{l}\tilde{n} \\
\infty \\
+1 \\
\vdots \\
\dot{0} \\
=\end{array}$ \\
\hline 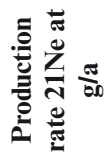 & $\underset{7}{-1}$ & $\hat{\bar{n}}$ & $\begin{array}{l}2 \\
\tilde{n} \\
\text { nิ }\end{array}$ & $\begin{array}{l}\bar{\sigma} \\
\text { ñ }\end{array}$ & $\begin{array}{l}\hat{R} \\
\hat{n}\end{array}$ & $\stackrel{\circ}{\circ}$ \\
\hline 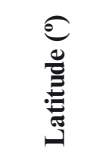 & 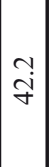 & $\overrightarrow{\widetilde{I}}$ & $\overrightarrow{\vec{f}}$ & $\overrightarrow{\mathcal{f}}$ & $\frac{\dot{F}}{\dot{\gamma}}$ & $\frac{\vartheta}{F}$ \\
\hline 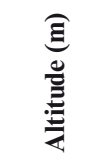 & $\stackrel{\circ}{\mathrm{I}}$ & \ั & 号 & 号 & $\begin{array}{l}\stackrel{2}{2} \\
\end{array}$ & $\stackrel{ }{=}$ \\
\hline 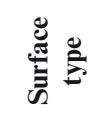 & $\sum_{i}$ & نे & 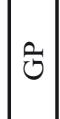 & $\sum_{\lrcorner}$ & 0 & ৩ি \\
\hline 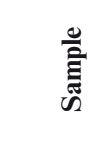 & 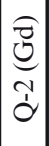 & 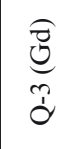 & 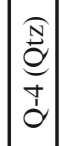 & $\begin{array}{l}\widehat{\theta} \\
0 \\
0 \\
0 \\
0\end{array}$ & $\frac{\widehat{\theta}}{0}$ & $\begin{array}{l}\vec{\theta} \\
\tilde{y} \\
\dot{x}\end{array}$ \\
\hline
\end{tabular}

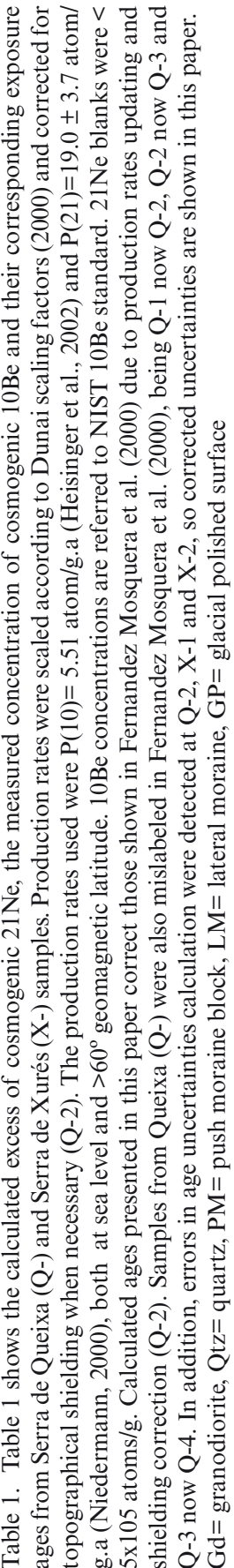




\section{DISCUSSION}

The glacial history that has been preserved in Serra de Queixa-Invernadoiro and Serra do Gerês-Xurés starts after the maximum glacial advance observed in the zone. But the geomorphological mapping without absolute datings only provides a relative sequence of glacial events. However, the chronology established by cosmogenic nuclides enables to give a new view to the subject though the reconstructed geomorphological history is very incomplete.

In Serra de Queixa-Invernadoiro (Figs $3 a$ and $b$ ), the glacial system had been in its maximum expansion when the Castiñeira moraine (Q-2) was formed. Its age of 155 \pm 30 ka B.P. $(21 \mathrm{Ne})$ coincides with a cold glacial episode in the Vostok ice core (Petit et al., 1999) and is set up within the marine isotopic stage 6 . The height of the moraine above the bottom of the present valley indicates a maximum thickness of the ice cap of about $200 \mathrm{~m}$. The thickness of the moraine in its ending part, hardly $2 \mathrm{~m}$, and its beveled morphology indicate a unique episode of glacial advance. Moreover, in front of the Castiñeiras moraine the features of the terrain change suddenly: the bedrock appears covered by a thick mantle of granite regolith and small granite rock residuals (tor and castellated rock type) outcrop frequently, thus proving that the glacial advance never exceeded this point. For the Spanish Pyrenees, Peña et al. (2004) establish the oldest Pleistocene glacial stage for this zone, the Sabiñánigo Phase, whose age was set up by OSL in fluvioglacial terraces in $155 \pm 24$ and $156 \pm 10 \mathrm{ka}$ B.P., the same as for Q-2.

Q-6 $(85 \pm 24$ ka B.P. $(21 \mathrm{Ne}))$ dates the division of the unique, former ice cap of Que-
ixa-Invernadoiro into two separated masses: the Conso and the Cerveira areas. Its height over the bottom of the present valley gives a thickness of the ice cap at this point of about $167 \mathrm{~m}$. The obtained age could be assigned to the end of the marine isotopic stage 5a. According to Peña et al. (2004), in the Spanish Pyrenees the Aurín Phase, dated in $85 \pm 5 \mathrm{ka}$ B.P. by OSL in fluvioglacial terraces, corresponds to Q-6, again coinciding the chronology of the glaciation of the Spanish Pyrenees with that of Serra de Queixa-Invernadoiro.

Q-3 marks the end of the construction of the Chaguazoso moraine, and the ages, $22 \pm 17$ ka B.P. $(21 \mathrm{Ne})$ and $24 \pm 2$ ka B.P. (10Be), coincide substantially and represent the end of a long cold period associated to marine isotopic stages 2 and 3 . The Chaguazoso moraine is characterized by its big dimensions (40 m thick). This suggests that this last accretion should retrieve for a long time producing the great accumulation. In another peninsular glaciated zone located in the Sierra de Guadarrama, Spanish Central System, in the glacial cirque of Peñalara, a push moraine with similar characteristics (35 $\mathrm{m}$ thick) has a similar age determined by $10 \mathrm{Be}$ (Pedraza personal communication). This may indicate a stability for this stage of the Iberian glaciations, with continued small advances and retreats that explain the huge development in height of moraines. This stage is also the last maximum extent in the Pyrenees (Pallás et al., 2006) and in the major ice sheets of Britain and Scandinavia (Hughes et al., 2006).

Q-4 in Serra de Queixa-Invernadoiro gave an age of $16 \pm 7 \mathrm{ka}$ B.P. $(21 \mathrm{Ne})$ and $14 \pm 2$ ka B.P. (10Be), yielded again good agreement between both cosmogenic nuclides. It corresponds to the very end of 
the deglaciation stage of the sierra. By the same time Laguna Grande-As Lamas silting begins (13,4 \pm 4 ka B.P.) (Vidal Romaní and Santos, 1993; Ramil-Rego et al., 1998).

In Serra do Gerês-Xurés (Figs 4a and b) the chronological record is older and reaches up to marine isotopic stage 8 . X-2, $231 \pm 48$ ka B.P. $(21 \mathrm{Ne})$, corresponds to a glacial expansion with diffluence from the Portuguese zone to the Spanish one (Vidal Romaní et al., $1990 \mathrm{a}$ and b). At that moment the maximum thickness of the ice cap should be similar to the ones of Serra de Queixa-Invernadoiro. X-2 is located among 3 morainic ridges: one corresponding to an advanced pulsation, and the other two formed in one later pulsation (Brum et al., 1992), though all of them within the diffluence stage.

$\mathrm{X}-1,135 \pm 31 \mathrm{ka}$ B.P. $(21 \mathrm{Ne})$, marks the end of the diffluence into the Spanish zone, and, therefore, the beginning of the deglaciation, falling into the marine isotopic stage 5e. The oldest sample dated in the Massif of Queixa-Invernadoiro would correspond to an intermediate stage between X-2 and X-1 in Serra do Gerês-Xurés.

Based on our data, the glacial maximum in Serra do Gerês-Xurés would be the oldest date known up to now for the glaciarism in the whole Iberian Peninsula. There exists a reference of a glaciation in the French Pyrenees (Quinif and Maire 1996) with a similar age $(225+14.7 /-12.8 \mathrm{ka}$ B.P) determined by $234 \mathrm{U} / 238$ from a speleothem.

\section{CONCLUSIONS}

The study of the glacial dynamics in two areas of the NW Iberia has posed many challenges for years. The glaciation developed over granitic bedrock with a poor and bad differentiated sedimentary and geomor- phological record. Thus, the geomorphological data only allowed the establishment of a relative sequence of events. The area affected by the glaciation has been established by direct (micromorphology of lodgement till, morphoscopy of quartz grains at the SEM) and indirect (presence of regolith, granite residuals) criteria, these latter exclusive of non-glaciated zones. The absolute chronology has been determined by two cosmogenic nuclides (10Be and $21 \mathrm{Ne}$ ) that show a good correlation grade between them. The ages obtained for these massifs are also found in other glaciated massifs of Iberia (Pyreneans, Central System) dated by cosmogenics $10 \mathrm{Be}$, OSL or by $234 \mathrm{U} / 238 \mathrm{U}$. There also exists a good correlation grade with the cold phases marked by the marine isotopic stages of the Vostok ice core. Our work allowed us to distinguish glacial stages corresponding to 3 different glacial isotopic stages, the age of the morainic blocks coinciding with glacial advances and the age of the polish surfaces with deglaciation stages (Petit et al., 1999). The combined use of geomorphological, micromorphological and SEM techniques and cosmogenic nuclides was very useful to define the glacial dynamics and chronology of these small ice caps separated from the main glaciation.

\section{ACKNOWLEDGEMENTS}

This work has been financed with the Project CGL2004-06516/BTE of the Ministry of Education and Science of Spain. We thank Aurora Grandal for her help in the drawing of the figures and Ana Martelli for the translation of the text into English and the writing style corrections. Dr Gonzalo Vieira and an anonymous reviewer greatly contributed to improve the original. 


\section{REFERENCES.}

Bordonau, J., 1992. Els complexos glàciolacustres relacionats amb el darrer cicle glacial als Pirineus. Geoforma Ed. Logroño. 251pp.

Brum, A., Vidal Romaní, J.R., Vilaplana, J. M., Rodrígues, M.L., Zézere, J.L. and Monge, C., 1992. Formas e depósitos glaciários e periglaciários da Serra do Gerês-Xurés (Portugal; Galicia). Levantamento cartográfico. Cuadernos do Laboratorio Xeolóxico de Laxe, 17, 121-135.

Brum, A., Vidal Romaní, J.R., Vilaplana, J.M., Rodrígues, M.L., Zézere, J.L. and Monge, C., 1993. Formas e depósitos glaciarios e periglaciarios da Serra do Gerês-Xurés. Ourense. Levantamiento Cartográfico. Actas III Reunión Nacional del Cuaternario Ibérico Lisboa 1993. G.T.P.E.Q-G.E.T.C., 87-98.

Cerling, T.E. and Craig, H., 1994. Geomorphology and in situ cosmogenic isotopes. Annual Review of Earth and Planetary Science. 22, 273-317.

Cottard F., 1979. Petrologie structurale et métallogénie du complexe granitique de Lovios-Gerês. Le modéle de mise en place de la mine de Las Sombras (Sn-W-Mo-Bi) (Sud Galice-Espagne). Tesis Doctoral. Paris, France, 226 pp.(unpublished)

Coudé-Gaussen, G., 1978. Confirmation de l'existence d'une glaciation würmienne dans les montagnes du NW du Portugal. Comptes Rendues sommaires de la Societé Geologique de France 1, 34-37.

Coudé-Gaussen, G., 1980. Les serras orientales du Minho (Portugal): orogenèse, modelè granitique et altèrations. Revue de Geographie des Pyrénées et du SudOuest. 51-3, 291-313.
Coudé-Gaussen, G., 1981. Les Serras da Peneda et do Gerês. Étude Géomorphologique. Memorias do Centro de Estudos Geográficos. 5, 254.

De Uña, E. and Vidal Romaní, J.R., 2000. Procesos degradativos en antiguas superficies grabadas sobre granitos: indicadores de magnitud y patrones de estado. Geogaceta 28, 145-148.

Dunai, T.J., 2000. Scaling factors for production rates of in situ produced cosmogenic nuclides: a critical reevaluation. Earth and Planetary Science Letters 176, 157-169.

Dunne, J., Elmore, D. and Muzikar, P., 1999. Scaling factors for the rates of production of cosmogenic nuclides for geometric shielding and attenuation at depth on sloped surfaces. Geomorphology 27, 3-11.

Fernández Mosquera, D., Marti, K., Vidal Romaní, J.R. and Weigel, D., 2000. Late Pleistocene deglaciation chronology in the NW of the Iberian Peninsula using cosmic-ray produced $21 \mathrm{Ne}$ in quartz. Nuclear Instruments and Methods in Physical Research B, 1-6.

Fernández, F. and Pilas, E., 1974 a. Mapa Geológico de Lovios. Hoja 301. Serie MAGNA. Servicio de Publicaciones I.G.M.E. Madrid, Spain.

Fernández, F. and Pilas, E., 1974 b. Mapa Geológico de Portela d区Home. Hoja 336. Serie MAGNA. Servicio de Publicaciones I.G.M.E. Madrid, Spain.

Hernández-Pacheco, F., 1949. Huellas glaciares en la Sierra de Queija. Boletín de la Real Sociedad Española de Historia Natural. 47, 97-102.

Hernández-Pacheco, F., 1957. EI glaciarismo cuaternario en la Sierra de Queija (Orense). Boletín de la Real Sociedad Española de Historia Natural. 55, 27-74. 
Hughes P.D., Woodward J.C. and Gibbard P.L., 2006. Quaternary glacial history of he Mediterranean mountains. Progress in Physical Geography 30, 3, 334.364.

Hult, R., 1873. Fran Nord till Syd Kalender Fjallvandringar i Galicien och Zamora. Geografiska Foreningen i Finland, 3055. Helsingfords.

Jiménez, M., 1996. El glaciarismo en la cuenca alta del Rio Nalón (NO de España): una propuesta de evolución de los sistemas glaciares cuaternarios en la Cordillera Cantábrica. Revista de la Sociedad Geológica de España, 9, 3-4, 157-168.

Kohl, P. and Nishiizumi, K., 1992. Chemical isolation of quartz for measurement of in-situ-produced cosmogenic isotopes. Geochimica et Cosmochimica Acta, v.56, 3583-3587.

Maldonado, F., 1994. Evolución tardiglaciar y holocena de la vegetación en los macizos del Noroeste Peninsular. Tesis doctoral, E.T.S. de Ingenieros de Montes, 171. Madrid, Spain. (unpublished).

Martínez de Pisón E. and Arenillas M., 1979. Algunos problemas de morfología glaciar en la España atlántica. Acta Geológica Hispánica, 14, 445-450.

Martínez de Pisón E. and Arenillas M., 1984. Nuevos problemas de morfología glaciar en la España Atlántica. Estudios Geográficos. C.S.I.C. Madrid, Spain, 175, 159-174.

Niedermann S., Graf T. and Marti K., 1993. Mass spectrometric identification of cosmic-ray-produced neon in terrestrial rocks with multiple neon components. Earth and Planetary Science Letters, 118, 65-73.

Niedermann S., Graf T., Kim J. S., Kohl C. P., Marti K. and Nishiizumi K., 1994.
Cosmic-ray-produced $21 \mathrm{Ne}$ in terrestrial quartz: the neon inventory of Sierra Nevada quartz separates. Earth and Planetary Science Letters, 125, 341-355.

Niedermann, S., 2000. The $21 \mathrm{Ne}$ production rate in quartz revisited. Earth and Planetary Science Letters 183, 361-364.

Pallás R, Rodés A, Braucher R, Carcailler J., Ortuño M., Bordonau J., Bourlés D., Vilaplana J.M., Masana E. and Santanach P., 2006. Late Pleistocene and Holocene glaciation in the Pyrenees: a critical review and new evidence from $10 \mathrm{Be}$ exposure ages, south-central Pyrenees. Quaternary Science Reviews. 25, 29372963.

Peña J.L., Sancho C., Lewis C., Mcdonald E. and Rhodes E., 2004. Datos cronológicos de las morrenas terminales del Gállego y su relación con las terrazas fluvioglaciares (Pirineos de Huesca). Geografía Física de Aragón. Aspectos generales y temáticos, pp 71-84. Zaragoza (Spain).

Pérez-González, A., Cabra, P., Martín, A., Capote, R., De Vicente, G., Rubio, J.M., Gallardo, J., Martín, J.L., Aguirre, E., Santonja, M., Vidal Romaní, J.R., Hoyos, M., Serrat, D., Gutiérrez Elorza, M., Peña Monne, J.L., Molina, E., De Pedraza, J., Rodríguez Vidal, J., Díaz del Olmo, F., Goy, J.L., Zazo, C., Baena, J., Del Olmo, P., Meco, J., Rey, J., Medialdea, T., Peralta, M., Díaz, L.A. and Calderón, V., 1989. Mapa del Cuaternario de España. Servicio de Publicaciones 1.T.G.E., Madrid, Spain, 279.

Petit, J.R., Jouzel, J., Raynaud, D., Barkov, N.I., Barnola, J.M., Basile, I., Bender, M., Chapellaz, J., Davis, M., Deaygue, G., Delmotte, M., Kotlyakov, V.M., Legrand, M., Lipenkov, V.Y., Lorius, 
C., Pepin, L., Ritz, C., Saltzman, E. and Stievenard, M., 1999. Climate and atmospheric history of the past 420,000 years from the Vostok ice core, Antarctica. Nature, 399, 429-436.

Quinif, Y. and Maire, R., 1996. Pleistocene deposits in Pierre Saint-Martin Cave, French Pyrenees. Quaternary Research, 49, 37-50.

Ramil-Rego, P., Muñoz, C. and Rodríguez M.A., 1998. Differences in the vegetation of the North Iberian peninsula during the last 16,000 years. Plant Ecology, 138, 41-62.

Rubio, J. and Rodríguez, L. R., 1981. Mapa Geológico de España escala 1:50.000, $\mathrm{n}^{\circ}$ 227/8-11, Manzaneda. Instituto Geológico y Minero. Madrid, Spain, $2^{\mathrm{a}}$ serie, $1^{\mathrm{a}}$ edición.

Schmidt-Thomé, P., 1973. Neue niedrig gelegene zeugen einer wurmeis-zetlichen vergletscherung im nordteil der Iberischen halbinsel. Eizeitalter Und Gegenwart, 24, 384-389.

Schmidt-Thomé, P., 1983. Besonders niedrig gelegene zeugen einer wurmeiszeitlichen vereibung in nord-west Spanien und nord Portugal. Spat-imd Postglaziale Gletscherschwankungen Glazial und Periglazial Formen. Colloquium, 1980 Rotterdam. 21, 3-230.

Soares de Carvalho, G. and Lopes Nunes, J., 1981. Comentarios sobre imagens de factos denunciantes de processos glaciarios quaternarios nas Serras do Gerês e da Peneda Portugal. Memorias e Noticias. 91-92. 164-171.

Teixeira, C. and Cardoso, J.L., 1979. A não confirmação de fenomenos glaciários nas montanhas do norte de Portugal (Peneda-Gerês). Boletim da Sociedade Geológica de Portugal. XXI, 11-111, 163-184.
Texier, J.P. and Meireles, J., 2003. Relict mountain slope deposits of northern Portugal and environmental implications. Journal of Quaternary Science 18(2) 133-150.

Twidale, C.R. and Vidal Romaní, J.R., 2005. Landforms and geology of granite terrains. Balkema, Amsterdam, Holanda 351 pp.

Vidal Romaní, J.R., Brum, A., Zezere J., Rodrigues, L. and Monge, C., 1990a. Evolución cuaternaria del relieve granítico en la Serra de Gerês-Xurés (Minho Portugal y Ourense Galicia). Cuaternario y Geomorfología, S.E.G.-A.E.QUA., 4: 3-12.

Vidal Romaní, J.R., Vilaplana, J. M., Brum, A., Zezere, J., Rodrígues, M.L. and Monge, C., 1990b. Estudio de los till subglaciares de la Serra de Gerês-Xurés (Minho Portugal Ourense Galicia). Cuaternario y Geomorfología, S.E.G.A.E.QUA., 4, 13-25.

Vidal Romaní, J.R. and Santos, M.L., 1993. Cronología relativa del máximo glaciar finipleistoceno en el sector nor-oriental de la Serra de Queixa (Ourense Galicia España). Actas $3^{\text {a }}$ Reunião do Quaternario Ibérico.Coimbra, Portugal. G.T.P.E.Q.-G.E.T.C., 215-222.

Vidal Romaní, J.R., Santos, L. and Jalut, G., 1995. Cronología relativa del máximo glaciar finipleistoceno en el sector NorOriental de la Serra de Queixa (Ourense, Galicia, España). Actas III Reunión del Cuaternario Ibérico, G.T.P.E.Q.G.E.T.C., 215-222.

Vidal Romaní, J.R., Fernández, D., Marti, K. and De Brum, A., 1999. Nuevos datos para la cronología glaciar pleistocena en el NW de la Península Ibérica. Cadernos do Laboratorio Xeolóxico de Laxe, 24, 7-29. 
Vilaplana, J.M., 1981. El método de trabajo utilizado en el estudio del glaciarismo cuaternario del Pirineo y su posible apli- cación en las sierras galaico-portuguesas. Cadernos do Laboratorio Xeolóxico de Laxe. 2, 259-288. 